\title{
APPLICATION OF THE AHP/ANP IN FOOD QUALITY MANAGEMENT
}

\author{
Anna Greda \\ Warsaw University \\ Department of Management \\ Warsaw, Poland \\ E-mail: akgreda2004@yahoo.com
}

\begin{abstract}
The objective of the present study is to demonstrate the application of multicriteria decision making methods in selecting the most efficient option of quality management system in food industry. Most studies concentrate on single aspects of quality management, instead of looking at the problem more holistically by analysing all factors and often complex relations between them. In response to this shortage, the present study proposes a more holistic model of successful quality management of food products. The Analytic Hierarchy/Network Process (AHP/ANP) were applied to build and analyse the problem. The successful quality management has been defined here as a goal of improving the quality of food products and increasing the company management effectiveness. The overall model comprises Benefits, Opportunities, Costs and Risks and consider a range of various factors influencing the decision problem. The AHP/ANP results are based on empirical survey (questionnaire interviews) carried out with managers in three leading food enterprises in Poland. The problem presented in this paper is very important not only in Poland. B,O,C,R models of improving the quality of food products and increasing the company management effectiveness can be successfully applied by food enterprises to choose the most appropriate quality management systems. Other methods applied to solve this problem would likely fail to analyse these dependencies so thoroughly. Last but not least, the rules of building the B,O,C,R models to select the best option of quality management system in food industry can also be applied in other than food companies.
\end{abstract}

Keywords: quality management, food products, BOCR analysis, AHP/ANP

\section{Introduction}

Nowadays, the concept of "quality" is very important in any branch of production and services. Since the beginning of the 90's a great deal of attention in Poland has been devoted to "quality management". Yet, our theoretical and practical experiences in this area are not as advanced as those in the USA, Japan or Western Europe, where the notion of "quality" has begun to develop from the 50 's.

Over the past decades, food quality and safety has become a very sensitive subject (KolozynKrajewska and Sikora, 2004). The recent food scandals, such as BSE, dioxins, melamine in baby formula, heavy metals in food, methanol in alcoholic beverages, bacterias in food (e.g. Salmonella, Campylobacter, E. coli) have greatly undermined the consumer confidence in food industry. For that reason, safety and wholesomeness of food products are adjudge as the most important cases. These features are invisible and consumer has to believe in producer's declaration. Therefore food producers', to satisfy consumer and gain his confidence to quality and safety on firm's products, implementing and certifying quality management systems and standards. Besides, producers put effort to get certificates for implementing systems, also to gain quality prizes and signs for their products (Greda, 2005).

The present study puts emphasis on quality and its importance in food production. Thus, it is nessesary to define the terms "quality" and "quality management". In general context, "quality" can be defined in many ways and has a lot of meanings. The most universal definition states that "quality" is a capability to satisfying and sometimes exceed the consumers' needs and expectations", while "quality 
management" is understood as "co-ordinated actions of managing the organization and its supervising with respect to the quality".

Nowadays, if Polish food companies want to succeed at the EU and the global market, they have to offer high-quality, cheaper, innovative and ecological products, as demanded by the consumer. Products with such features increase the consumer satisfaction, which is the crucial aspect of being successful in a highly competitive setting. Hence, the companies has turned their attention to all aspects related to product quality and its management (Greda, $2008 \mathrm{a}$ ).

A relatively large number of publications in this field deal only with costs and benefits of quality management, while only a few consider opportunities and risks thereof. Besides, most studies concentrate on individual aspects of quality management, instead of looking at the problem more holistically by analysing all factors and often complex relations between them (Lisiecka, 2000; Luning, et al, 2005; Wysokinska - Senkus, 2007; Zymonik, 2003).

The objective of the present study is to demonstrate the application of multicriteria decision making methods in selecting the most efficient option of quality management system in food industry. The Analytic Hierarchy/Network Process (AHP/ANP) were applied to build and analyse the problem.

\section{Methodology - Analytic Network Process (ANP)}

The Analytic Network Process (ANP) is a new theory that extends the Analytic Hierarchy Process (AHP). Its basic structures are networks, which undergo interactions and feedbacks within and between the clusters. So, it can be applied for solving more sophisticated decision problems (Saaty, 2001).

To remind shortly the steps in choosing the best alternative with using the Analytic Network Process (ANP) are as follows (Saaty, 2004 a; Adamus and Greda, 2005):

1. Define a decision-making problem and present it in form of a general goal to be achieved.

2. Decompose the problem into a network with four sub-networks, namely: Benefits (B), Opportunities (O), Costs (C) and Risks (R) (BOCR). In each of them, we distinguished: goal (defined under the Step 1), criteria, sub-criteria (...) and alternatives.

3. Define clusters of elements and their mutual connections, according to their internal and external dependencies and influences, considering each control criterion and sub-criterion under B,O,C,R.

4. Pairwise comparisons of connected elements inside the clusters (internal dependence) and between them (external dependence) using the Saaty's fundamental scale $(1-9)$ in each B,O,C,R network. We have to answer four kinds of questions in the ANP. In Benefits (B) subnet: given a criterion, which of two elements are more benefticial with respect to that criterion? Similar questions are asked in Opportunities (O) subnet. The best alternative has the highest priorities for Benefits and Opportunities. In Costs (C) or Risks (R) decision subnet we have to answer: which element is more costly or risky? The worst alternative has the highest priorities for Costs and Risks.

5. Pairwise comparisons of clusters of elements with respect to their influence on the control criterion in each of the B,O,C,R decision subnets. These weights are used to evaluate elements of respective blocks of supermatrix columns.

6. Synthesize results for each alternative in the B,O,C,R subnets. We choose the best alternative by using multiplicative formula $(\mathrm{BO} / \mathrm{CR})$ and additive - negative formula $(\mathrm{bB}+\mathrm{oO}-\mathrm{cC}-\mathrm{rR})$. In the latter formula the importance of each subnet e.i. Benefits (B), Opportunities (O), Costs (C), Risks (R) must be estimated by creating strategic criteria ratings model and prioritize the $\mathrm{B}, \mathrm{O}, \mathrm{C}, \mathrm{R}$.

7. Perform sensitivity analysis of the final result. The analysis concerns ,what-if” questions. 


\section{ANP Model}

The AHP/ANP method was used to structure a decision making problem concerning selection of the best combination of quality management systems in food companies. The AHP/ANP model was created following a review of the existing studies regarding the application and functioning of quality management systems (particularly in food industry), and as such of a combination of various evidence and theories (Adamus and Greda, 2004; Bednarczyk, 2005; Bieganowski and Bartnik, 2003; Ciechan Kujawa, 2003; Gieryń, 2006; Greda, 2008 b; Horubała, 1995; ISO 15161; Kijowski and Sikora, 2003; Owczarek and Bieganowski, 2003).

\subsection{Respondents}

The AHP/ANP results are based on empirical survey (questionnaire interviews) carried out with managers in three leading food enterprises in Poland. These companies were large international corporations, their products are known globally. Each company has also been rewarded for the quality of the products as well as for the overall activity (i.e. research, charity). The aim was to ask about the improvement of the quality management systems since these companies are known to have a great experience in implementation and certification of the quality management systems at the market. In each of them, quality systems were presented in integrated form (mostly by documents and common policy of quality management). Overall, 86 respondents were interviewed.

\subsection{AHP/ANP models}

Application of the Analytic Network Process allows more explorative and thorough analysis of factors contributing to select the optimal alternative, which represents a combination of the quality management systems used in food industry.

In the constructed ANP model, the main goal is "improving the quality of food products and increasing the company management effectiveness", in terms of four networks: Benefits, Opportunities, Costs and Risks. The B,O,C,R analysis of this interdisciplinary problem extends the analogous analysis solved by the AHP hierarchies of Costs and Benefits. The outcomes are more reliable and accurate than in the Analytic Hierarchy Process, because the ANP models consist of the networks of mutual influences and feedbacks between the most important factors in decision making process.

The ANP decision networks of Benefits and Costs have been derived based on the AHP analysis of this problem, and supplemented by additional influences between elements, inside and outside of the clusters. These models were broadened by including additional decision networks of Opportunities and Risks that were not included in the AHP analysis.

Figure 3 presents the ANP model for Benefits. Four areas of the company activities (organisational, production, technological and economic) have been considered as control criteria with respect to three alternative quality management systems:

A. The system of food safety assurance (GMP/GHP, HACCP);

B. The system of quality management of food products (GMP/GHP, HACCP, ISO 9001);

C. The integrated system of quality management of food products (GMP/GHP, HACCP, ISO 9001, ISO 14001, PN-N/OHSAS 18001).

Alternative A is a combination of Good Manufacture Practice (GMP), Good Hygienic Practice (GHP) and Hazard Analysis and Critical Control Point (HACCP). They are obligatory in all food companies, and GMP/GHP are prerequisite programs of HACCP.

Alternative B comprises the same obligatory systems as A (GMP/GHP and HACCP), but additionally includes ISO 9001 norms. This alternative is the most common solution in the majority of food enterprises.

The third alternative (C) embraces all the above GMP/GHP, HACCP and ISO 9001, with additional systems ISO 14001 and PN-N/OHSAS 18001. This option includes the Environmental Management 
norm ISO 14001 because food production is also connected with waste production and pollution of the environment. Finally, safe work conditions should be an integral component of each industrial activity, thus occupational health and safety standards (PN-N/OHSAS 18001) were also added to this model.

Process approach to quality management in ISO 9001 norms helps to integrate this system with ISO 14001 and PN-N/OHSAS 18001 (Skrzypek and Hofman, 2006). This approach can be supported by guidelines PAS 99:2006 (Publicly Available Specification) published by BSI in 2006, containing basic requirements that help in systems integration (Kleniewski, 2007).

Quality management systems can be integrated in three ways: (1) building integrated system from the beginning, (2) gradual incorporation of new systems into the existing ones, or (3) implementation of each quality system separately and managing them individually. The second option is the most frequently applied and perhaps the optimal way, because enterprise's knows the system's work and it's easier to accept demanding of a new implementing quality system (Tabor and Raczka, 2004).

In a similar way, the ANP models were prepared for Costs (Figure 2), Opportunities (Figure 3) and Risks (Figure 4). Each network includes organisational, production, technological and economic criteria (areas of company activities), corresponding subcriteria and decision alternatives explained above (A, B, C). Chapter 4 describes steps in analysis of the whole model and summarizes the results.

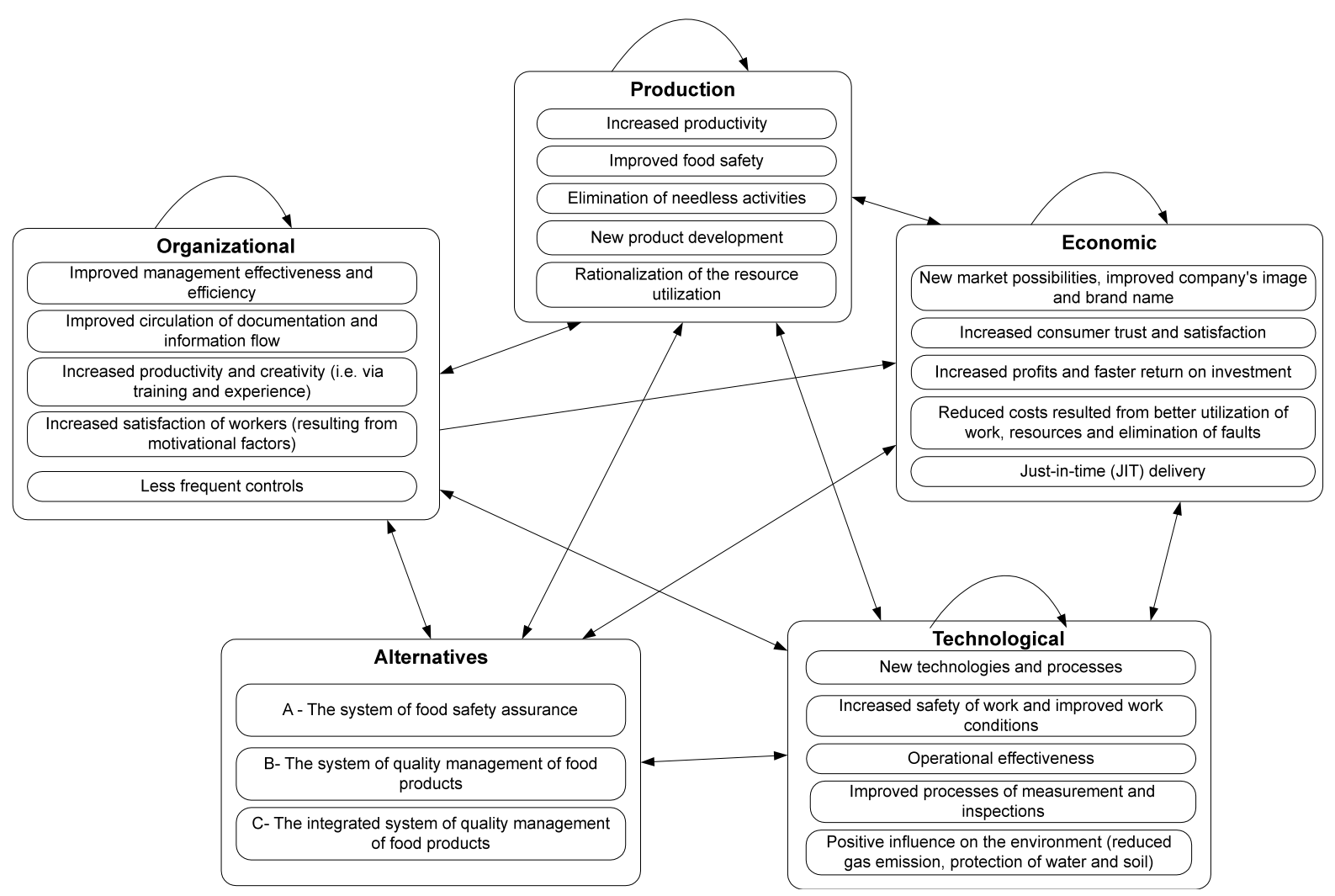

Figure 1. ANP model for Benefits of, improving the quality of food products and increasing the company management effectiveness" 


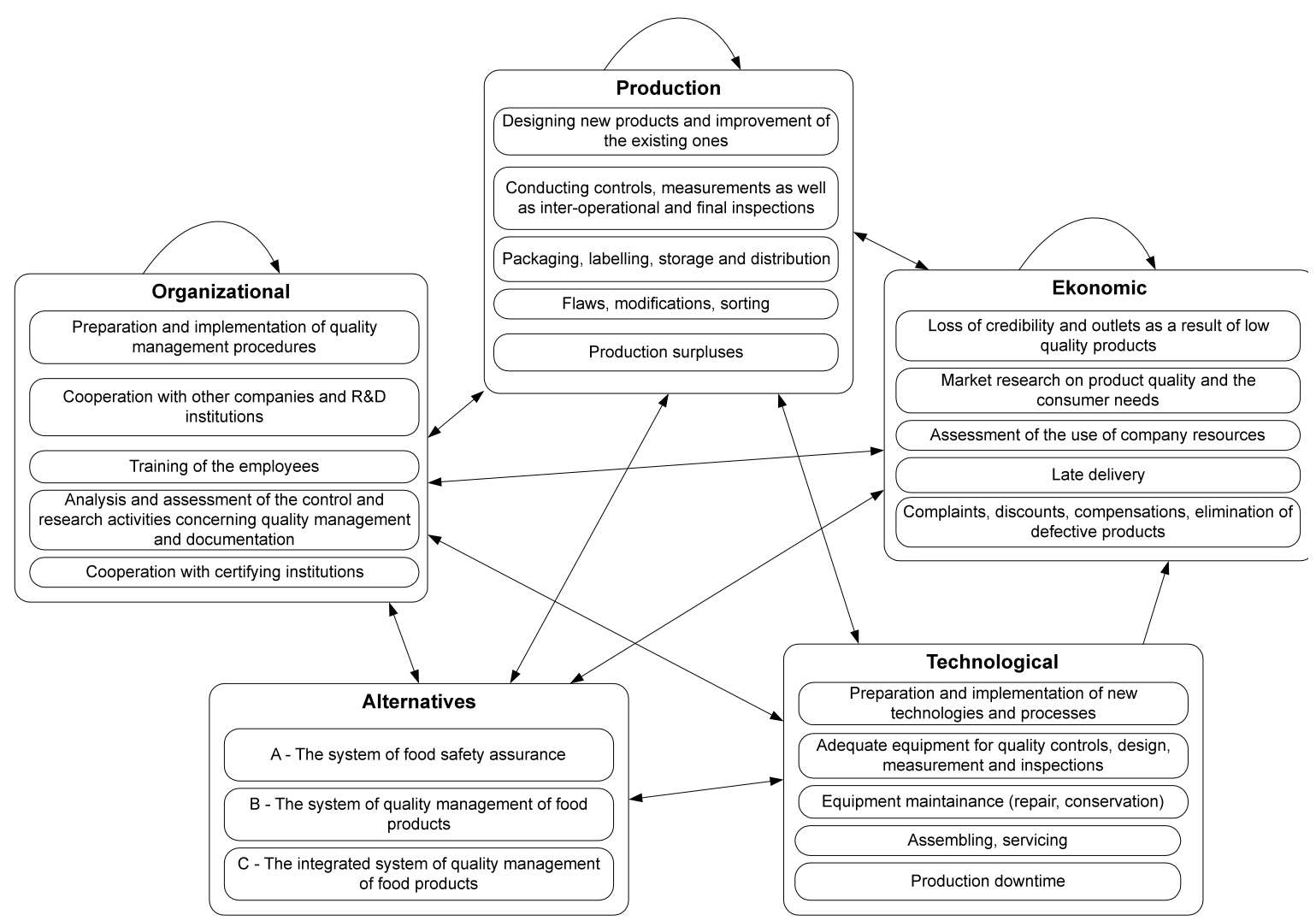

Figure 2. ANP model for Costs of ,improving the quality of food products and increasing the company management effectiveness"

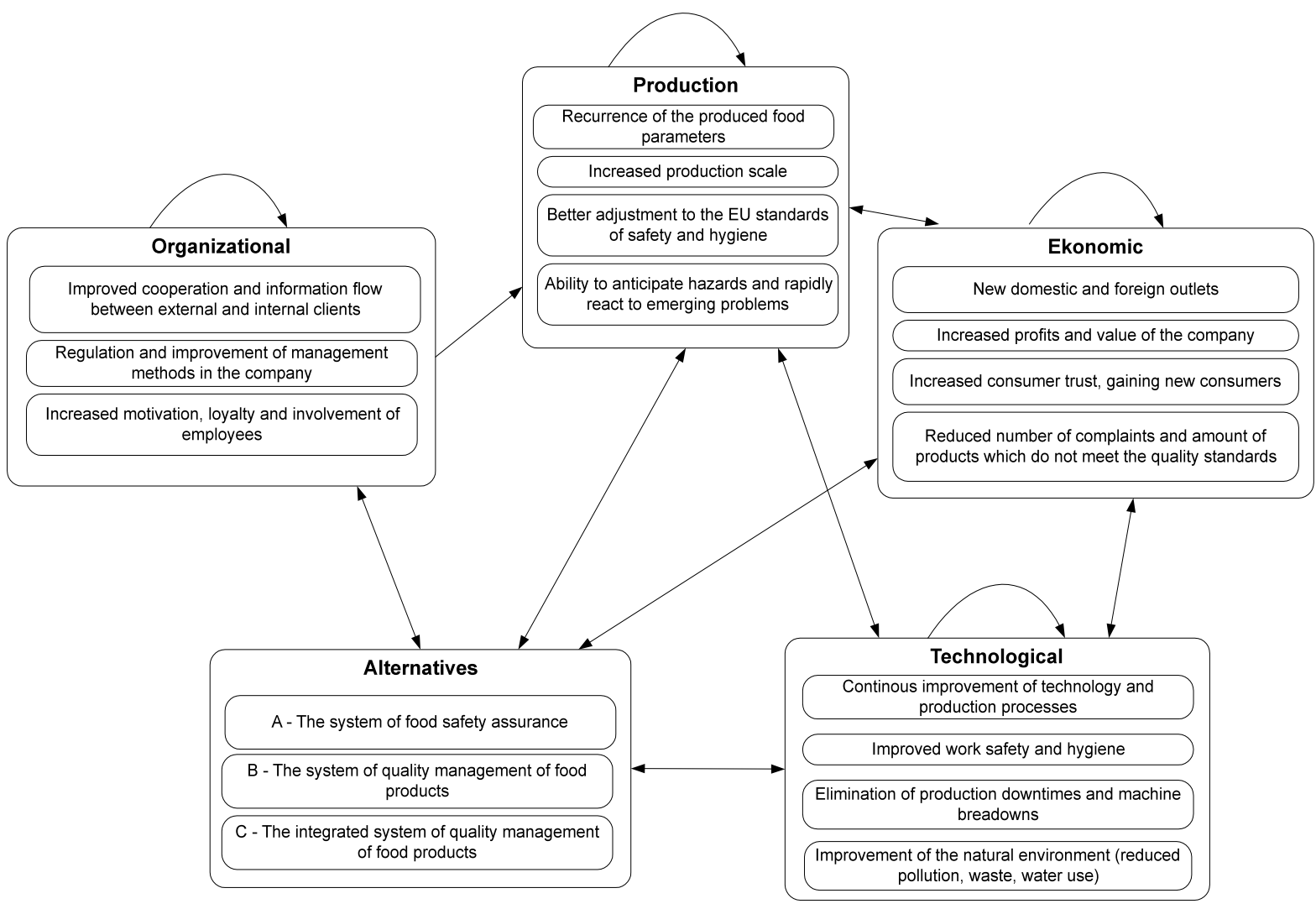

Figure 3. ANP model for Opportunities of „improving the quality of food products and increasing the company management effectiveness" 


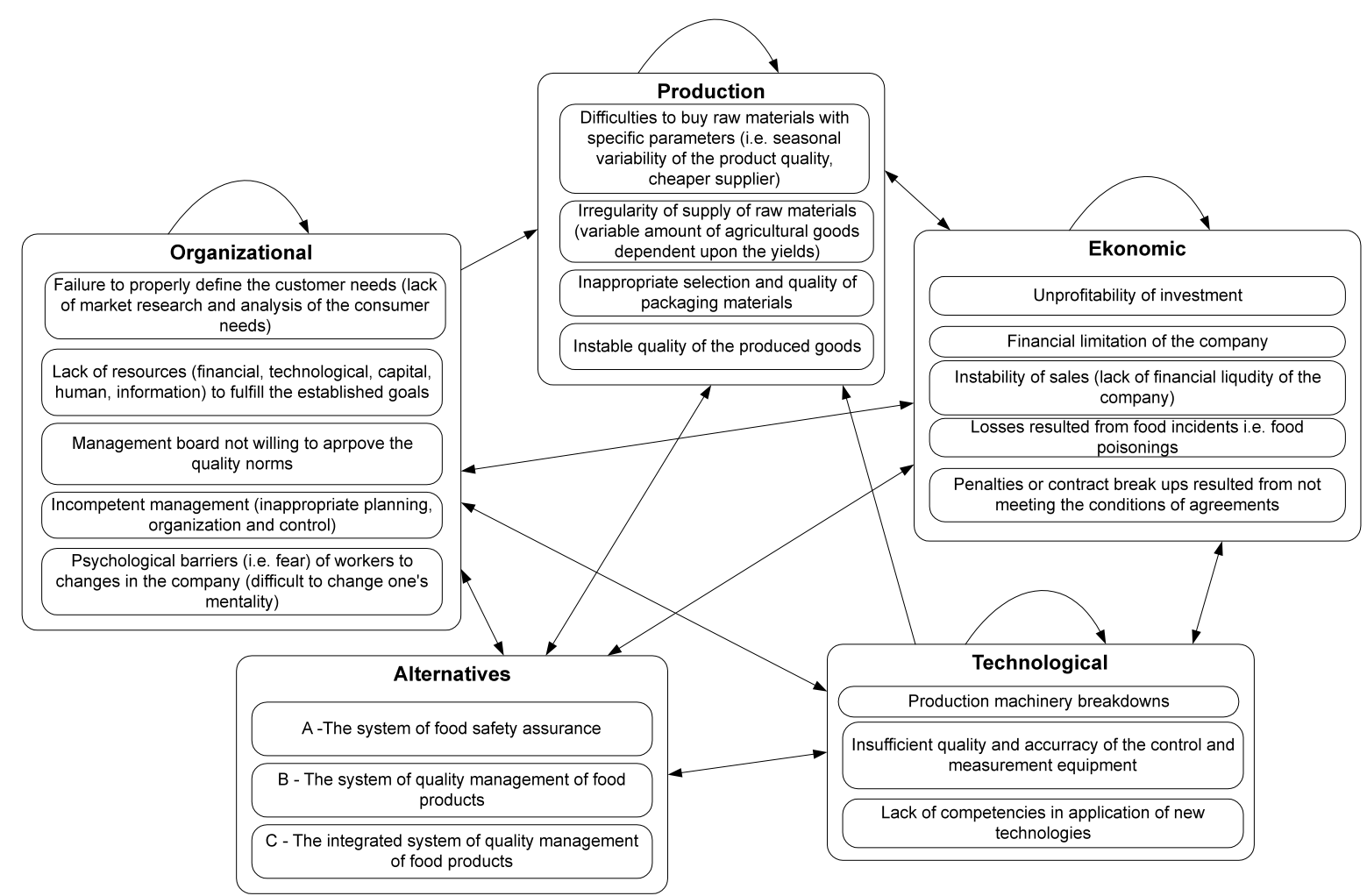

Figure 4. ANP model for Risks of, ,improving the quality of food products and increasing the company management effectiveness"

\section{Analysis and Results}

The ANP analysis comprises seven steps as described in Chapter 2. Construction of the BOCR model (Chapter 3) was followed by its analysis using pairwise comparisons of the elements according to the Saaty's 9-point scale. Pairwise comparisons have been performed within and between each group of decision factors. To make the final decision, which is choosing the best alternative to improve the quality of food products and increase the company management effectiveness, all factors from the B,O,C,R models were analyzed using Super Decisions software. The objective is to find the alternative that is most beneficial and offers most opportunities while at the same time representing the lowest risk and the lowest costs variant.

In the ANP model of Benefits 214 pairwise comparisons have been performed (Figure 1), in case of Opportunities (Figure 2) - 148 pairwise comparisons, in Costs (Figure 3) - 257, while in Risks (Figure $4)-188$. The overall amount of pairwise comparisons in the whole ANP model was 807. The CR index was lower than $10 \%$ in all pairwise comparisons matrices of $\mathrm{B}, \mathrm{O}, \mathrm{C}, \mathrm{R}$ models. Table 1 presents local and global priorities for 72 subcriteria in the ANP model of Benefits, Opportunities, Costs and Risks. These results were integrated for all experts calculated as geometric means of the outcomes.

Table 1. Prioritization of ANP control criteria and subcriteria of Benefits (B), Opportunities (O), Costs (C) and Risks (R)

\begin{tabular}{|l|l|l|l|l|}
\hline Merits & Criteria & Subcriteria & $\begin{array}{l}\text { Local } \\
\text { priorities }\end{array}$ & $\begin{array}{l}\text { Global } \\
\text { priorities }\end{array}$ \\
\hline \multirow{5}{*}{ Organizational } & Improved management effectiveness and efficiency & 0,2334 & 0,0174 \\
\cline { 3 - 5 } & $\begin{array}{l}\text { Improved circulation of documentation and } \\
\text { information flow }\end{array}$ & 0,1033 & 0,0077 \\
\cline { 3 - 5 } & $\begin{array}{l}\text { Increased productivity and creativity (i.e. via training } \\
\text { and experience) }\end{array}$ & 0,1950 & 0,0146 \\
\hline
\end{tabular}




\begin{tabular}{|c|c|c|c|c|}
\hline \multirow[t]{20}{*}{ Benefis (B) } & & $\begin{array}{l}\text { Increased satisfaction of workers (resulting from } \\
\text { motivational factors) }\end{array}$ & 0,1614 & 0,0120 \\
\hline & & Less frequent controls & 0,3069 & 0,0229 \\
\hline & \multirow{5}{*}{ Production } & Increased productivity & 0,1268 & 0,0393 \\
\hline & & Improved food safety & 0,3958 & 0,1225 \\
\hline & & Elimination of needless activities & 0,1005 & 0,0311 \\
\hline & & New product development & 0,2145 & 0,0664 \\
\hline & & Rationalization of the resource utilization & 0,1624 & $\mathbf{0 , 0 5 0 3}$ \\
\hline & \multirow{5}{*}{ Technological } & New technologies and processes & 0,1786 & 0,0298 \\
\hline & & $\begin{array}{l}\begin{array}{l}\text { Increased safety of work and improved work } \\
\text { conditions }\end{array} \\
\end{array}$ & 0,2414 & $\mathbf{0 , 0 4 0 3}$ \\
\hline & & Operational effectiveness & 0,3504 & $\mathbf{0 , 0 5 8 5}$ \\
\hline & & Improved processes of measurement and inspections & 0,0886 & 0,0148 \\
\hline & & $\begin{array}{l}\text { Positive influence on the environment (reduced gas } \\
\text { emission, protection of water and soil) }\end{array}$ & 0,1410 & 0,0235 \\
\hline & \multirow{5}{*}{ Economic } & $\begin{array}{l}\text { New market possibilities, improved company's image } \\
\text { and brand name }\end{array}$ & 0,2195 & 0,0183 \\
\hline & & Increased consumer trust and satisfaction & 0,1377 & 0,0115 \\
\hline & & Increased profits and faster return on investment & 0,2299 & 0,0192 \\
\hline & & $\begin{array}{l}\text { Reduced costs resulted from better utilization of work, } \\
\text { resources and elimination of faults }\end{array}$ & 0,2124 & 0,0177 \\
\hline & & Just-in-time (JIT) delivery & 0,2003 & 0,0167 \\
\hline & \multirow{3}{*}{ Alternatives } & A A & 0,1621 & 0,0593 \\
\hline & & $\mathrm{B}$ & 0,2313 & 0,0845 \\
\hline & & $\mathrm{C}$ & 0,6066 & 0,2217 \\
\hline \multirow{25}{*}{ Costs (C) } & \multirow{5}{*}{ Organisational } & $\begin{array}{lccc}\begin{array}{l}\text { Preparation and implementation } \\
\text { management procedures }\end{array} & \text { of quality } \\
\end{array}$ & 0,0541 & 0,0090 \\
\hline & & $\begin{array}{l}\text { Cooperation with other companies and R\&D } \\
\text { institutions }\end{array}$ & 0,0189 & 0,0032 \\
\hline & & Training of the employees & 0,5637 & 0,0940 \\
\hline & & $\begin{array}{l}\text { Analysis and assessment of the control and research } \\
\text { activities concerning quality management and } \\
\text { documentation }\end{array}$ & 0,2147 & 0,0358 \\
\hline & & Cooperation with certifying institutions & 0,1486 & 0,0248 \\
\hline & \multirow{5}{*}{ Production } & $\begin{array}{l}\text { Designing new products and improvement of the } \\
\text { existing ones }\end{array}$ & 0,1386 & 0,0389 \\
\hline & & $\begin{array}{l}\text { Conducting controls, measurements as well as inter- } \\
\text { operational and final inspections }\end{array}$ & 0,3897 & 0,1092 \\
\hline & & Packaging, labelling, storage and distribution & 0,4006 & $\mathbf{0 , 1 1 2 3}$ \\
\hline & & Flaws, modifications, sorting & 0,0301 & 0,0084 \\
\hline & & Production surpluses & 0,0410 & 0,0115 \\
\hline & \multirow{5}{*}{ Technological } & $\begin{array}{l}\text { Preparation and implementation of new technologies } \\
\text { and processes }\end{array}$ & 0,1663 & 0,0297 \\
\hline & & $\begin{array}{l}\text { Adequate equipment for quality controls, design, } \\
\text { measurement and inspections }\end{array}$ & 0,5010 & 0,0895 \\
\hline & & Equipment maintainance (repair, conservation) & 0,2076 & 0,0371 \\
\hline & & Assembling, servicing & 0,0838 & 0,0150 \\
\hline & & Production downtime & 0,0413 & 0,0074 \\
\hline & \multirow{5}{*}{ Economic } & $\begin{array}{l}\text { Loss of credibility and outlets as a result of low quality } \\
\text { products }\end{array}$ & 0,1773 & 0,0197 \\
\hline & & $\begin{array}{l}\text { Market research on product quality and the consumer } \\
\text { needs }\end{array}$ & 0,1708 & 0,0197 \\
\hline & & Assessment of the use of company resources & 0,1659 & 0,0185 \\
\hline & & Late delivery & 0,0734 & 0,0082 \\
\hline & & $\begin{array}{l}\text { Complaints, discounts, compensations, elimination of } \\
\text { defective products }\end{array}$ & 0,4125 & 0,0459 \\
\hline & \multirow{3}{*}{ Alternatives } & $\overline{\mathrm{A}}$ & 0,1866 & 0,1997 \\
\hline & & $\mathrm{B}$ & 0,2474 & 0,1913 \\
\hline & & $\mathrm{C}$ & 0,5659 & 0,1489 \\
\hline & \multirow[b]{2}{*}{ Organisational } & $\begin{array}{l}\text { Improved cooperation and information flow between } \\
\text { external and internal clients }\end{array}$ & 0,6686 & 0,0221 \\
\hline & & $\begin{array}{l}\text { Regulation and improvement of management methods } \\
\text { in the company }\end{array}$ & 0,1919 & 0,0063 \\
\hline
\end{tabular}




\begin{tabular}{|c|c|c|c|c|}
\hline \multirow[t]{16}{*}{$\begin{array}{l}\text { Opportunities } \\
\text { (O) }\end{array}$} & & $\begin{array}{l}\text { Increased motivation, loyalty and involvement of } \\
\text { employees }\end{array}$ & 0,1394 & 0,0046 \\
\hline & \multirow{4}{*}{ Production } & Recurrence of the produced food parameters & 0,1907 & $\mathbf{0 , 0 4 2 8}$ \\
\hline & & Increased production scale & 0,0770 & 0,0173 \\
\hline & & $\begin{array}{l}\text { Better adjustment to the EU standards of safety and } \\
\text { hygiene }\end{array}$ & 0,3453 & $\mathbf{0 , 0 7 7 5}$ \\
\hline & & $\begin{array}{l}\text { Ability to anticipate hazards and rapidly react to } \\
\text { emerging problems }\end{array}$ & 0,3869 & 0,0868 \\
\hline & \multirow{4}{*}{ Technological } & $\begin{array}{l}\text { Continous improvement of technology and production } \\
\text { processes }\end{array}$ & 0,2626 & $\overline{\mathbf{0 , 0 5 2 3}}$ \\
\hline & & Improved work safety and hygiene & 0,3650 & $\mathbf{0 , 0 7 2 7}$ \\
\hline & & $\begin{array}{l}\text { Elimination of production downtimes and machine } \\
\text { breadowns }\end{array}$ & 0,3005 & $\mathbf{0 , 0 5 9 8}$ \\
\hline & & $\begin{array}{l}\text { Improvement of the natural environment (reduced } \\
\text { pollution, waste, water use) }\end{array}$ & 0,0719 & 0,0143 \\
\hline & \multirow{4}{*}{ Economic } & New domestic and foreign outlets & 0,3046 & $\mathbf{0 , 0 3 4 2}$ \\
\hline & & Increased profits and value of the company & 0,2219 & 0,0249 \\
\hline & & Increased consumer trust, gaining new consumers & 0,2078 & 0,0233 \\
\hline & & $\begin{array}{l}\text { Reduced number of complaints and amount of } \\
\text { products which do not meet the quality standards }\end{array}$ & 0,2657 & 0,0298 \\
\hline & \multirow{3}{*}{ Alternatives } & $\mathrm{A}$ & 0,1619 & 0,0698 \\
\hline & & $\mathrm{B}$ & 0,2018 & 0,0870 \\
\hline & & $\mathrm{C}$ & 0,6363 & 0,2744 \\
\hline \multirow{20}{*}{ Risks (R) } & \multirow{5}{*}{ Organizational } & $\begin{array}{l}\text { Failure to properly define the customer needs (lack of } \\
\text { market research and analysis of the consumer needs) }\end{array}$ & 0,3331 & 0,1388 \\
\hline & & $\begin{array}{l}\text { Lack of resources (financial, technological, capital, } \\
\text { human, information) to fulfill the established goals }\end{array}$ & 0,5159 & $\mathbf{0 , 2 1 5 0}$ \\
\hline & & $\begin{array}{l}\text { Management board not willing to aprove the quality } \\
\text { norms }\end{array}$ & 0,0486 & 0,0203 \\
\hline & & $\begin{array}{l}\text { Incompetent management (inappropriate planning, } \\
\text { organization and control) }\end{array}$ & 0,0494 & 0,0206 \\
\hline & & $\begin{array}{l}\text { Psychological barriers (i.e. fear) of workers to changes } \\
\text { in the company (difficult to change one's mentality) }\end{array}$ & 0,0529 & 0,0220 \\
\hline & \multirow[t]{4}{*}{ Production } & $\begin{array}{l}\text { Difficulties to buy raw materials with specific } \\
\text { parameters (i.e. seasonal variability of the product } \\
\text { quality, cheaper supplier) }\end{array}$ & 0,1516 & 0,0194 \\
\hline & & $\begin{array}{l}\text { Irregularity of supply of raw materials (variable } \\
\text { amount of agricultural goods dependent upon the } \\
\text { yields) }\end{array}$ & 0,0343 & 0,0044 \\
\hline & & $\begin{array}{l}\text { Inappropriate selection and quality of packaging } \\
\text { materials }\end{array}$ & 0,1400 & 0,0179 \\
\hline & & Instable quality of the produced goods & 0,6741 & $\mathbf{0 , 0 8 6 1}$ \\
\hline & \multirow{3}{*}{ Technological } & Production machinery breakdowns & 0,6656 & $\mathbf{0 , 0 3 1 6}$ \\
\hline & & $\begin{array}{l}\text { Insufficient quality and accurracy of the control and } \\
\text { measurement equipment }\end{array}$ & 0,1465 & 0,0069 \\
\hline & & $\begin{array}{l}\text { Lack of competencies in application of new } \\
\text { technologies }\end{array}$ & 0,1879 & 0,0089 \\
\hline & \multirow{5}{*}{ Economic } & Unprofitability of investment & 0,2261 & 0,0664 \\
\hline & & Financial limitation of the company & 0,1698 & 0,0499 \\
\hline & & $\begin{array}{l}\text { Instability of sales (lack of financial liqudity of the } \\
\text { company) }\end{array}$ & 0,4827 & 0,1418 \\
\hline & & $\begin{array}{l}\begin{array}{l}\text { Losses resulted from food incidents } \\
\text { poisonings }\end{array} \\
\end{array}$ & 0,0526 & 0,0155 \\
\hline & & $\begin{array}{l}\text { Penalties or contract break ups resulted from not } \\
\text { meeting the conditions of agreements }\end{array}$ & 0,0687 & 0,0220 \\
\hline & \multirow{3}{*}{ Alternatives } & 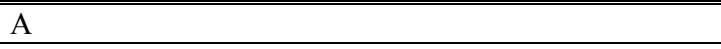 & 0,3008 & 0,0412 \\
\hline & & $\mathrm{B}$ & 0,2887 & 0,0330 \\
\hline & & $\mathrm{C}$ & 0,3506 & 0,0401 \\
\hline
\end{tabular}

According to the experts, the most beneficial elements are (Table 1$)$ : improved food safety $(0,1225)$, new product development $(0,0664)$, operational effectiveness $(0,0583)$. The highest priorities were received by decision elements concerning production and technological control criteria. 
In the Cost model, elements with the highest priorities were: packaging, labelling, storage and distribution $(0,1123)$, conducting controls, measurements as well as inter-operational and final inspections $(0,1092)$, training of the employees $(0,0940)$.

Improving the quality of food products may also bring opportunities such as ability to anticipate hazards and rapidly react to emerging problems $(0,0858)$, better adjustment to the EU standards of safety and hygiene $(0,0775)$, improved work safety and hygiene $(0,0727)$.

The analysis of local and global priorities for all factors from the ANP model of Risks showed that the most risky elements are those from organisational and economic activities. The highest priorities of risks were obtained by the lack of resources (financial, technological, capital, human, information) to fulfill the established goals $(0,2150)$, instability of sales (lack of financial liqudity of the company) 0,1418 , failure to properly define the customer needs (lack of market research and analysis of the consumer needs) $-0,1388$.

Results for global priorities for all factors included in the ANP model of Benefits are presented in Figure 5, Opportunities in Figure 6, Costs in Figure 7 and Risks in Figure 8.

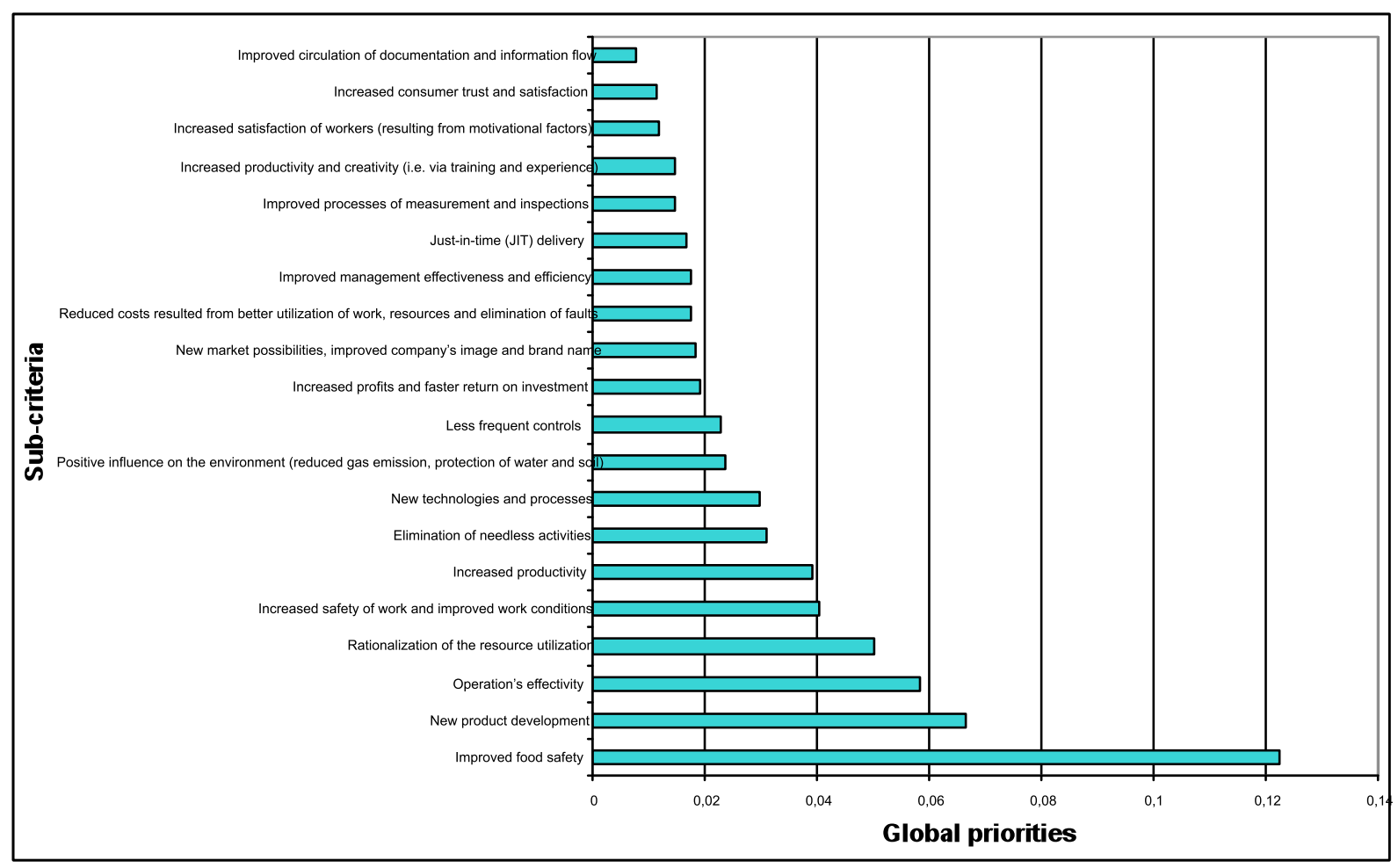

Figure 5. Global priorities of subcriteria in the ANP model of Benefits 


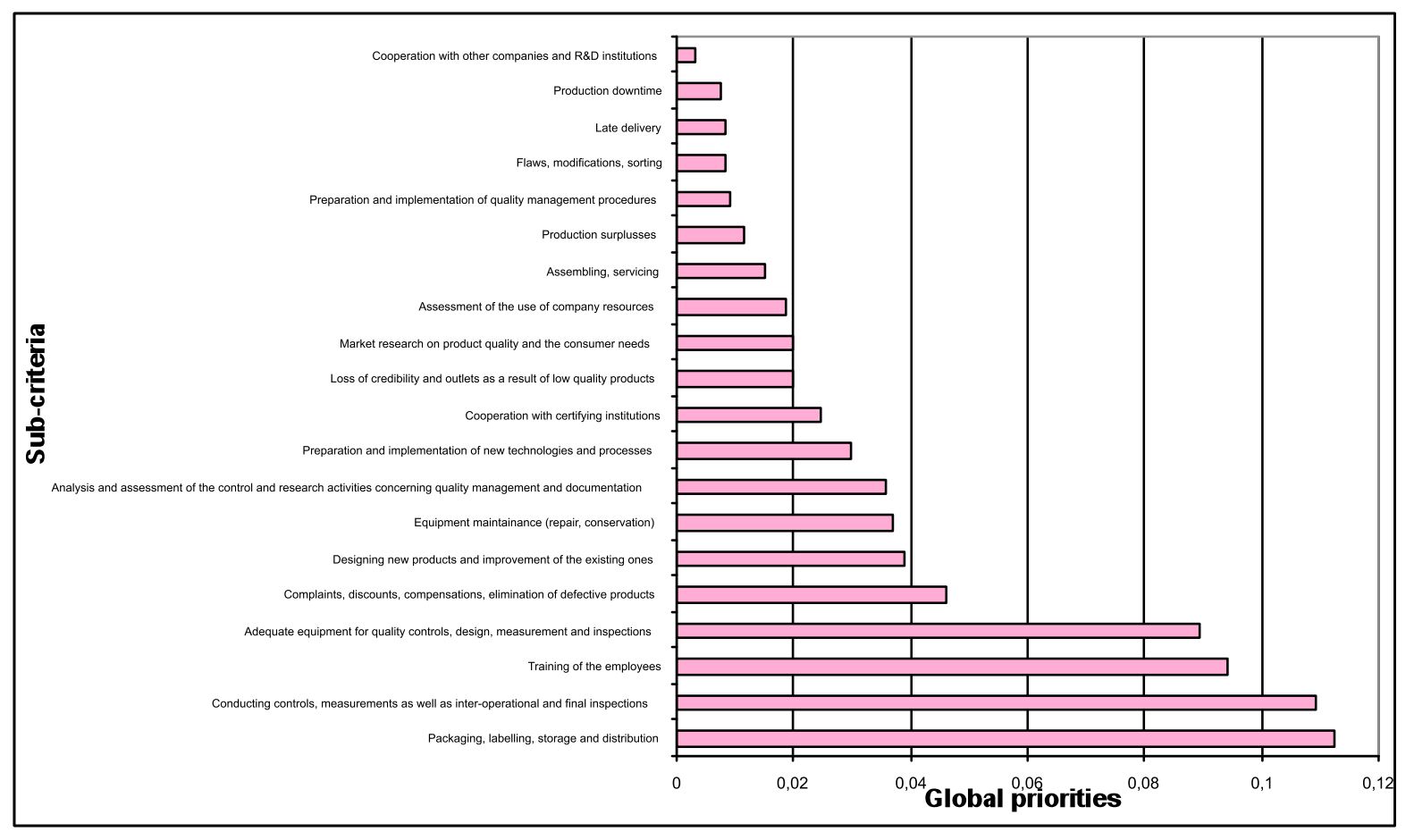

Figure 6. Global priorities of subcriteria in the ANP model of Costs

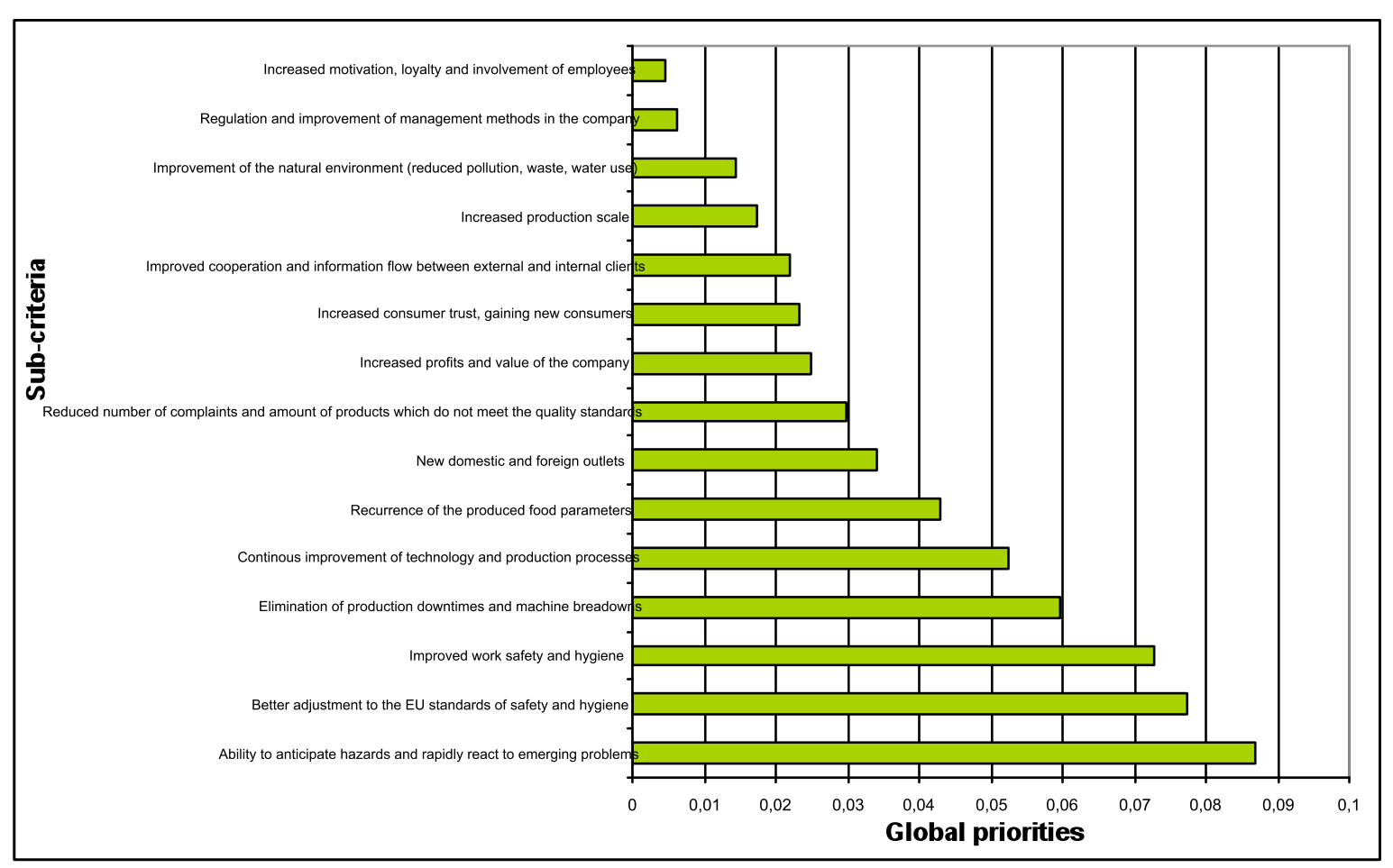

Figure 7. Global priorities of subcriteria in the ANP model of Opportunities 


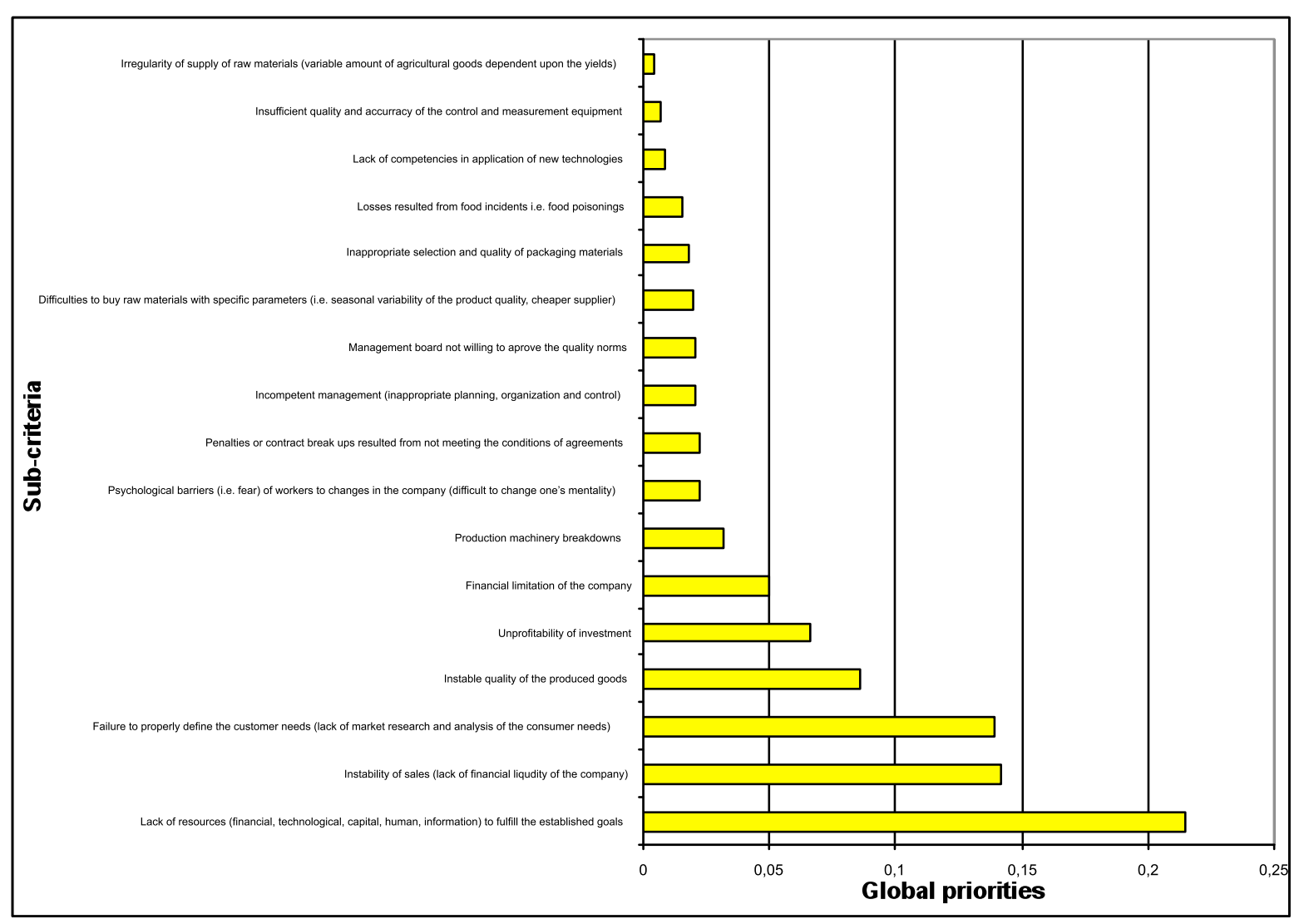

Figure 8. Global priorities of subcriteria in the ANP model of Risks

Subcriteria with global priorities higher than $0,03(3 \%)$ were the most important in decision process and had the biggest influence on choosing the best alternative of improving the quality of food products and increasing the company management effectiveness. To make the final decision, it was necessary to consider all factors and combine their results. It was possible by using two mathematical formulae of ANP: multiplicative $(\mathrm{BO} / \mathrm{CR})$ and additive - negative $(\mathrm{bB}+\mathrm{oO}-\mathrm{cC}-\mathrm{rR})$. As regards the multiplicative formula, priorities of alternatives in Benefits and Opportunities models are divided by the respective priorities derived from Costs and Risks. The best alternative is the one with the highest value. However, this formula is used only if Benefits, Opportunities, Costs and Risks are considered equally important. Otherwise, additive-negative formula should be employed. Prior to do so, we need to define the importance of BOCR sub-systems (merits) by deriving strategic criteria (Saaty, $2004 \mathrm{~b}$ ). The strategic criteria are invariant criteria or objectives of an individual or organization that always need to be satisfied and are external to the actual decision model. Such representation let us look at the problem from more general perspective, including economic-production, social, political, image and educational criteria. The importance of merits was estimated by ranking of Benefits, Opportunities, Costs and Risks. The rating was made for top alternative from each BOCR network with respect to the strategic criteria. The strategic criteria model is presented in Figure 9. 


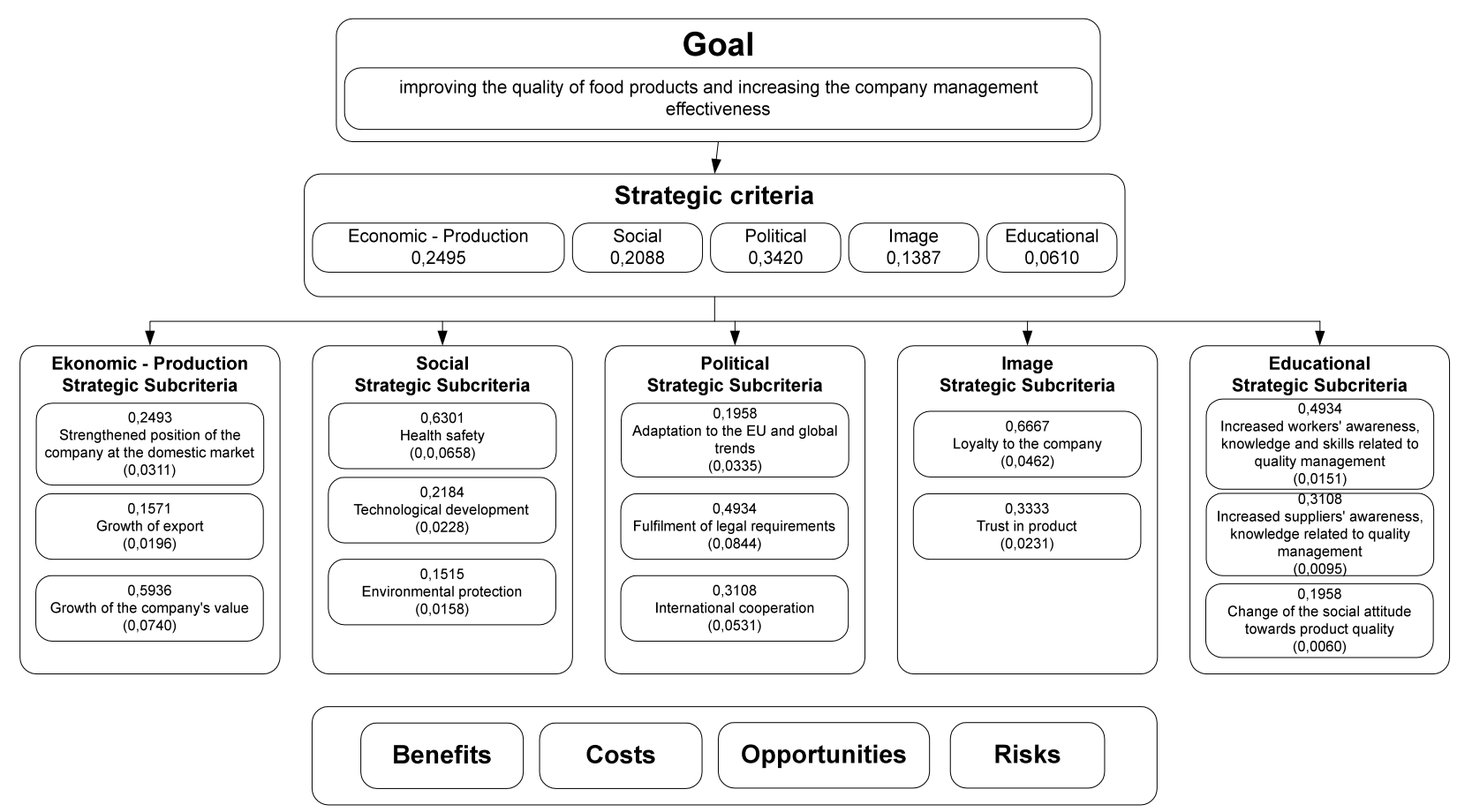

Figure 9. Strategic criteria model for "improving the quality of food products and increasing the company management effectiveness"

To perform the ranking, personal criteria were created (see the top of Table 2). Priorities for each subsystem (merit) were estimated though matching a given personal criterion to every strategic subcriterion and then summing up their weights. The ranking prepared for the merits $(B, O, C, R)$ shows that Benefits and Opportunities are the most significant in choosing the best (optimum) alternative of improving the quality of food products and increasing the company management effectiveness. They received the highest priorities: 0,3200 and 0,3161 , respectively.

Table 2. Priority estimation for merits: Benefits (B), Opportunities (O), Costs (C), Risks (R)

Very big $(0,3909)$; big $(0,2798)$; medium $(0,2041)$; small $(0,0753)$; very small $(0,0499)$

Very high $(0,4734)$; high $(0,2628)$; medium $(0,1442)$; low $(0,0716)$; very low $(0,0479)$

\begin{tabular}{|c|c|c|c|c|c|}
\hline Criteria & Subcriteria & Benefis (B) & Costs (C) & Opportunities (O) & Risks (R) \\
\hline \multirow{3}{*}{$\begin{array}{l}\text { Economic- } \\
\text { Production } \\
(0,2495)\end{array}$} & $\begin{array}{l}\text { Strengthened position of the company } \\
\text { at the domestic market }(0,0311)\end{array}$ & Very big & Medium & Very big & Very big \\
\hline & Growth of export $(0,0196)$ & Very big & Medium & Very big & Big \\
\hline & $\begin{array}{l}\text { Growth of the company's value } \\
(0,0740)\end{array}$ & Very big & Big & Big & Big \\
\hline \multirow{3}{*}{$\begin{array}{l}\text { Social } \\
(0,2088)\end{array}$} & Health safety $(0,0658)$ & Very big & Big & Very big & Small \\
\hline & Technological development $(0,0228)$ & Very high & High & Very high & Medium \\
\hline & Environmental protection $(0,0158)$ & Very big & Big & Very big & Very big \\
\hline \multirow{3}{*}{$\begin{array}{l}\text { Political } \\
(0,3420)\end{array}$} & $\begin{array}{l}\text { Fulfilment of legal requirements } \\
(0,0844)\end{array}$ & Very big & Małe & Very big & Małe \\
\hline & International cooperation $(0,0531)$ & Big & Medium & Very big & Big \\
\hline & $\begin{array}{l}\text { Adaptation to the EU and global trends } \\
(0,0335)\end{array}$ & Very big & Big & Very big & Big \\
\hline \multirow{2}{*}{$\begin{array}{l}\text { Portrait } \\
(0,1387)\end{array}$} & Trust in product $(0,0231)$ & Very high & High & Very high & High \\
\hline & Loyalty to the company $(0,0462)$ & Very high & Very high & Very high & Medium \\
\hline \multirow{2}{*}{$\begin{array}{l}\text { Educational } \\
(0,0610)\end{array}$} & $\begin{array}{l}\text { Increased workers' awareness, } \\
\text { knowledge and skills related to quality } \\
\text { management }(0,0151)\end{array}$ & Very big & Big & Very big & Big \\
\hline & 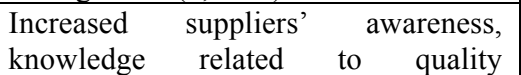 & Very big & Medium & Very big & Medium \\
\hline
\end{tabular}




\begin{tabular}{|l|l|l|l|l|l|}
\hline & management $(0,0095)$ & & & & Big \\
\cline { 2 - 6 } & $\begin{array}{l}\text { Change of the social attitude towards } \\
\text { product quality }(0,0060)\end{array}$ & Big & Medium & Big & $\mathbf{0 , 1 7 1 4}$ \\
\cline { 2 - 5 } & Priorities & $\mathbf{0 , 3 2 0 0}$ & $\mathbf{0 , 1 9 2 5}$ & $\mathbf{0 , 3 1 6 1}$ & \\
\hline
\end{tabular}

As a result of the BOCR analysis, the best is alternative $\mathrm{C}$ (the integrated system of quality management of food products). The choice of the best alternative was confirmed by two mathematical formulae. However, additive-negative formula gives negative results for alternative A. It means that it is not advisable for a food company to stay only with obligatory systems of quality management. A company should develop in order to meet the growing needs of the customers. Priorities for other alternatives were positive. Benefits and Opportunities surpass Costs and Risks in terms of implementation of the above alternatives. Final results are presented in Table 3.

Table 3. Final results of the ANP analysis

\begin{tabular}{|l|l|l|l|l|l|l|}
\hline Alternatives & $\begin{array}{l}\text { Benefits } \\
(0,3200)\end{array}$ & $\begin{array}{l}\text { Costs } \\
(0,1925)\end{array}$ & $\begin{array}{l}\text { Opportunities } \\
(0,3161)\end{array}$ & $\begin{array}{l}\text { Risks } \\
(0,1714)\end{array}$ & $\begin{array}{l}\text { Formula } \\
\text { BO/CR }\end{array}$ & $\begin{array}{l}\text { Formula } \\
\text { bB }+ \text { oO-cC-rR }\end{array}$ \\
\hline A & 0,2672 & 0,3297 & 0,2544 & 1,0000 & 0,2062 & $-0,0689$ \\
\hline B & 0,3813 & 0,4372 & 0,3171 & 0,8002 & 0,3456 & 0,0009 \\
\hline C & 1,0000 & 1,0000 & 1,0000 & 0,9718 & 1,0290 & 0,2770 \\
\hline
\end{tabular}

To check stability of the proposed solution, sensitivity analysis was performed for the ANP models of Benefits, Opportunities, Costs and Risks. It allows checking how the ultimate priorities solution would change if the values of BOCR increase or decrease.

From Figure 10 we can see that priorities of Benefits subnets do not have a big influence on the final results. Even if the priority for Benefits is lower than 0,32, alternative $\mathrm{C}$ is still the best solution. All lines in the sensitivity analysis graph for Benefits subnet displays a growing trend with the growing priority of Benefits. However, for the priority higher than 0,4 , this tendency starts changing for the integrated system of quality management of food products. The priority for this alternative is still optimal compared with other alternatives, but starts falling down. Sensitivity analysis for alternatives in Opportunities' model shows similar situation (insensitive to the changes) - Figure 11.

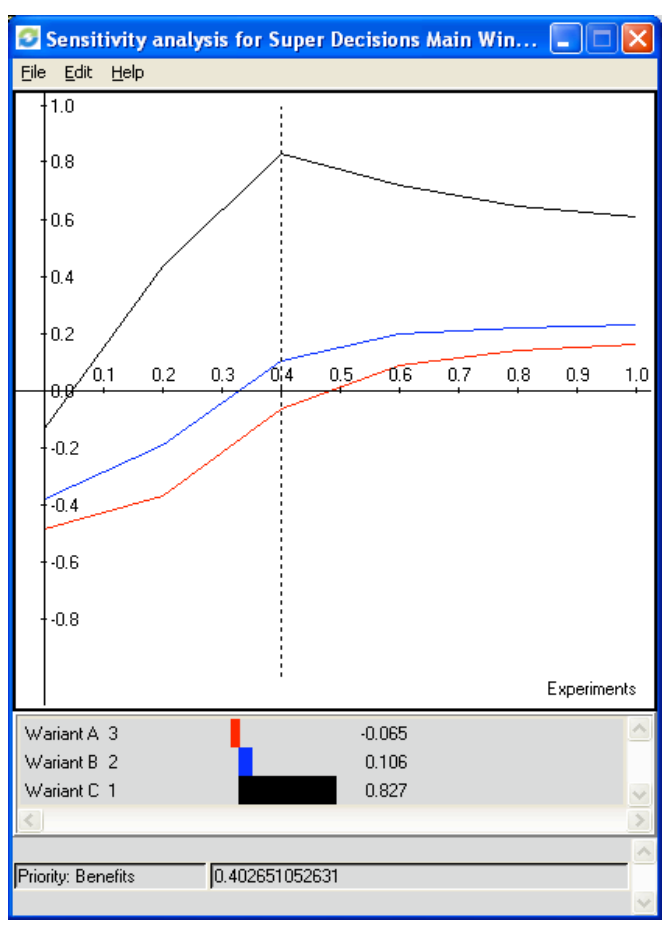

Figure 10. Sensitivity analysis for Benefits

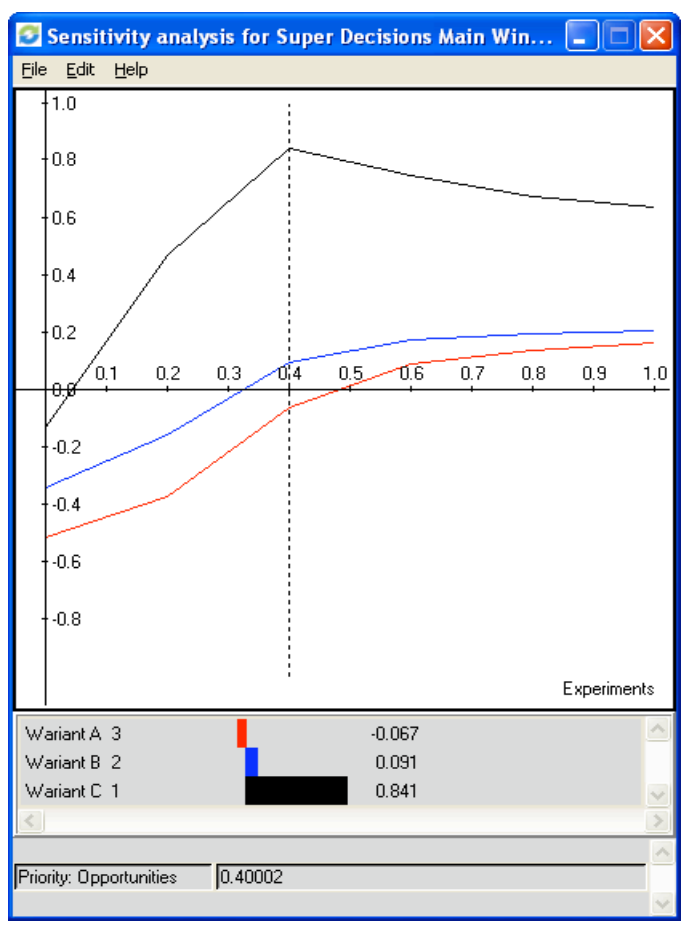

Figure 11. Sensitivity analysis for Opportunities 


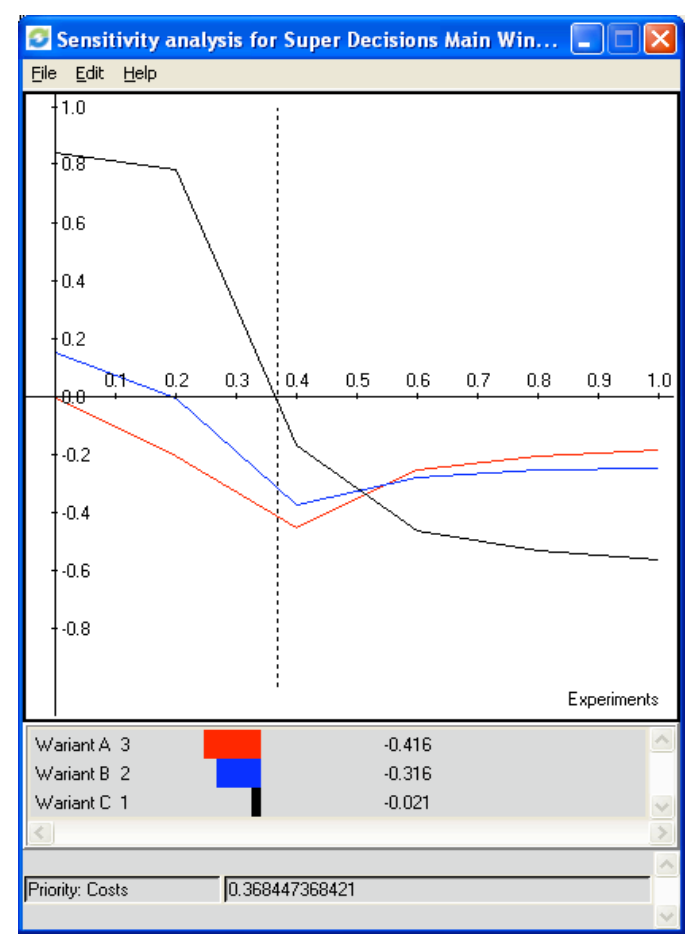

Figure 12. Sensitivity analysis for Costs

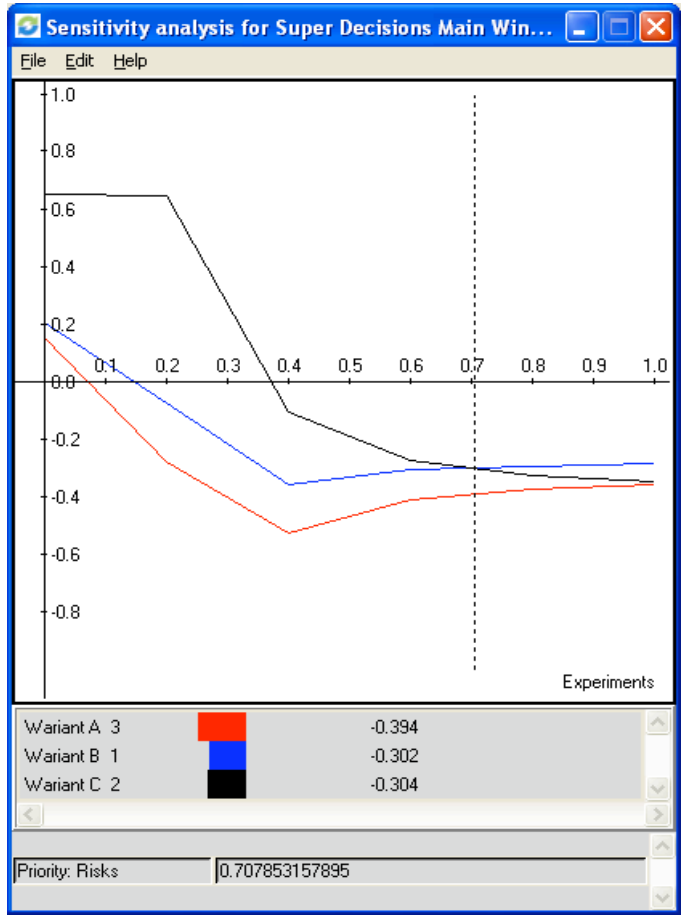

Figure 13. Sensitivity analysis for Risks

Graphs for alternatives in Costs' sensitivity analysis (Figure 12) show decreasing trend for all of them. It means that for the higher priority of the Costs subnets priorities for alternatives are lower. Alternative $\mathrm{C}$ is the best till the priority of Costs subnets equals 0,5. Above that value, this solution starts to be the worst. And then the best solution is alternative A.

In the sensitivity analysis for Risks (Figure 13), as in case of the Costs' sensitivity analysis, all graphs show downward tendency. The worst situation can be observed for alternative A. For the priority of Risks higher than 0,17 alternative $C$ starts falling down. This alternative $(C)$ is the best till the priority equals 0,7 . Above that value, this alternative occupies the second location (after the alternative B).

Overall, sensitivity analysis shows that priorities for all three alternatives (A, B and C) are more sensitive to changes of priorities for Costs and Risks subnets than for Benefits and Opportunities.

\section{Conclusions}

Polish food is perceived on the European market as high quality [Jendroszczyk, 2009]. However, to compete with products of other EU member states more efficiently, it is necessary to create mechanisms and technical conditions for producing safe food with high quality standards. At present, a company has to prove the consumer that the products are safe and high quality. Food safety is in fact the most important for the consumer and essential in food trade. The recent food incidents in various places of the globe forced Poland and many other countries to introduce restrictions on imported food. For that reason, from 1 May 2004, implementation of systems and standards of food hygiene and safety is mandatory for Polish food companies. The obligatory systems of food safety assurance are: Good Manufacture Practice (GMP), Good Hygienic Practice (GHP) and Hazard Analysis and Critical Control Point (HACCP).

Food safety is the subject of legal controls (the most recent Act of 25 August 2006), while other quality features are up to the consumer acceptance. Hence, food companies have to guarantee a certain level of quality of their products not only by implementing systems of food safety assurance, but also systems of quality management, e.g. norms ISO 9001. Moreover, food companies should extend their activity to environmental management (ISO 14001) and proceed to enlarge hygiene and safety of work 
e.g. by initiating the system PN-N/OHSAS 18001 (Urbaniak, 2007). Implementation of these systems cause gradual movement of food industry towards the concept of Total Quality Management (TQM).

It is advisable for the implemented systems to be integrated in a maximum way. They should form one united system realizing a common goal. In this case, it is reflected in the continuous improvement of the quality of food products. It should increase the consumer confidence in producers in local and global scale. Besides, this approach to the quality management, by involvement of all workers and "cells" in organization, helps to achieve high quality in all spheres of the company's activity. For many years, this type of management methods and production techniques have been used by leading organizations in the world.

To conclude, the problem presented in this paper is very important not only in Poland. The B,O,C,R models of improving the quality of food products and increasing the company management effectiveness can be successfully applied by food enterprises to choose the best quality management systems. The ANP models include every kind of dependencies and feedbacks between decision elements. Therefore, they reflect complexity of the problem and actual connections between factors inside and outside the firm. Other methods applied to solve this problem would likely fail to analyse these dependencies so thoroughly.

The final conclusions are as follows:

1. The AHP/ANP models accounts 72 (organisational, production, technological and economic) factors determing ,improving the quality of food products and increasing the company management effectiveness" in order to provide a more explorative view on this interdisciplinary problem.

2. The applied method (Analytic Network Process) enables observation of the complexity of the problem being solved, with its numerous internal and external interdependencies between factors in the B,O,C,R models. Besides, it let us answer the question: which alternative by realization of the most important factors contribute to improving the quality of food products and increasing the company management effectiveness?

3. The most costly factors of improving the quality of food products and increasing the company management effectiveness are:

a) packaging, labelling, storage and distribution $(0,1123)$;

b) conducting controls, measurements as well as inter-operational and final inspections $(0,1092)$

c) training of the employees $(0,0940)$.

4. The largest benefits, which result from improving the quality of food products and increasing the company management effectiveness are:

a) improved food safety $(0,1225)$;

b) new product development $(0,0664)$;

c) operational effectiveness $(0,0583)$.

5. Analysis of decision elements in the ANP model of opportunities shows that they mostly refer to:

a) ability to anticipate hazards and rapidly react to emerging problems $(0,0858)$;

b) better adjustment to the EU standards of safety and hygiene $(0,0775)$;

c) improved work safety and hygiene $(0,0727)$.

6. Among the factors with the highest priority of risk are the following:

a) lack of resources (financial, technological, capital, human, information) to fulfill the established goals $(0,2150)$;

b) instability of sales (lack of financial liqudity of the company) - 0,1418;

c) failure to properly define the customer needs (lack of market research and analysis of the consumer needs) $-0,1388$.

7. As a result of prioritization, two mathematical formulae (multiplicative and additive negative) give the same results for integrated system of quality management of food products as the best alternative. 
8. Sensitivity analysis may slightly change the priorities of alternatives, but would require extreme conditions for B,O,C,R prioritization and their control criteria.

9. The AHP/ANP were used to solve the most significant problems in all fields of science and practice. The author's intention was to show the usefulness of this method in addressing the problem of food quality management.

10. The principles of building the B,O,C,R models to select the best option of quality management system in food industry can also be applied in other than food companies.

\section{REFERENCES}

Adamus W., Greda A. (2004). The application of the Analytic Network Process to quality improvement of food products [in:] The conditioning of the enterprise's success in the knowledgebased economy. SUCCESS 2004. UMCS Lublin Publications, Vol. II, 379-391 (in polish).

Adamus W., Greda A. (2005). Multicriteria decission suport in solving organisational and management problems. Operation Research and Decisions, 2, 5 - 36 (in polish).

Bednarczyk K. (2005). The integrated systems of the quality management. Quality management in practice. Knowledge and Practician Publications, 4/5, 99- 102.

Bieganowski A., Bartnik G. (2003). The connection of the quality systems (ISO 9000) of agricultural producers and processing companies. Food Industry, 4, 40 - 43 (in polish).

Ciechan - Kujawa M. (2003). The calculation of the quality costs in practice of Polish enterprises. Quality Problems, 9, 30 - 34 (in polish).

Gieryn M. J. (2006). Risk analysis as a tool of the valuation of operations related to improvement of the quality management system. Quality Problems, 10, 17 - 21 (in polish).

Greda A. (2005). The quality management of food wholesomeness [in:] Acta Academiae Modrevianae, The chosen aspects of organisations management, (ed. W. Adamus). Krakow's Academy Publications, $264-279$ (in polish).

Greda A. (2008 a). Costs and Benefits of Improving Quality Management in a Multicriteria Framework [w:] Analytic Hierarchy and Network Process in Solving Economic, Organizational and Management Problems. Jagiellonian University Publications. Krakow (in print).

Greda A. (2008 b). Multicriteria analysis of BOCR in improving quality of food products [w:] OR 50, Conference Handbook, 9 - 11 September 2008, The Univeristy of York, The OR Society, England, 38 .

Horubala A. (1995). HACCP as a tool in controlling of the hygienic (sanitary) food quality. Food Technology-Quality, 2 (3), 2 - 9 (in polish).

ISO 15161: Guidelines of the application of ISO 9000:2000 for food and beverage industry.

Jendroszczyk P. (2009): Polish food tempted by the quality. Rzeczypospolita Daily Paper from 19.01.2009.

Kijowski J., Sikora T. (ed.) (2003). Management of food safety and quality. The systems' integration and computerization. WNT Publications. Warsaw (in polish).

Kleniewski A. (2007). The integration of management systems - PAS 99:2006 specification. Quality Problems, 10, 12 - 17 (in polish). 
Kolozyn - Krajewska D., Sikora T. (2004). The assurance of the quality and safety of food [in:] Materials from scientific session with cycle: The challenge of quality management. Economic University in Krakow Publications, 6 - 7 May 2004, 45 - 52 (in polish).

Luning P.A., Marcelis W.J., Jongen W.M. (2005). The quality management of food. Technologic manager conception. WNT Publications. Warsaw (in polish).

Owczarek L., Bieganowski A. (2003).The quality systems vs safety of food products. Food Industry, 2, 18-24 (in polish).

PN-EN ISO 14001:2005. Systems of Environmental Management. The specification and the guidelines of applying. The Polish Committee of Standardization. Warsaw. 2005 (in polish).

PN-EN ISO 9000:2001. Systems of Quality Management. Foundation and terminology. The Polish Committee of Standardization. Warsaw. 2001 (in polish).

PN-N-18001:2004. Systems of occupational health and safety. Requirements. The Polish Committee of Standardization. Warsaw. 2004 (in polish).

Saaty T. L. (2001). Decision Making with Dependence and Feedback. The Analytic Network Process. RWS Publications. Pittsburgh PA.

Saaty T. L. (2004 a). Decision Making - The Analytic Hierarchy and Network Processes (AHP/ANP), Journal of Systems Science and Systems Engineering, published at Tsinghua University, Beijing, Vol. 13, No 1, 1-34, March.

Saaty T. L. (2004 b). The Analytic Hierarchy and Analytic Network Processes for the Measurement of Intangibles and for Decision Making, 67 page chapter in Multiple Criteria Decision Analysis: The State of the Art Surveys. Kluwer Academic Publishers, Dordrecht, edited by Figueira, J., Greco, S. and Ehrgott, M.

Skrzypek E., Hofman M. (2006). The process management in Polish companies - research results. The merchandising quality problems, 4(9), 16 - 25 (in polish).

Tabor A., Rączka M. (2004). Modern quality management. Vol. III. The planning, initiation, preservation and improvement of the quality management systems. Krakow's Technical University Publications. Krakow (in polish).

The law from 25 August 2006 about food safety and nourishment (Law Journal 27 September 2006) No 171, position 1225 (in polish).

Urbaniak M. (2007). The quality management, as well as the natural environment and safety in economic practice. Difin Publications. Warsaw (in polish).

Wysokinska - Senkus A. (2007). The costs and benefits score of the quality management systems in the food industry. The Economists Association of Agriculture. Scientific Annuals Vol IX, copybook 3, $229-233$ (in polish).

Zymonik Z. (2003). The costs of the quality in company's management. Wroclaw Technical University Publications Outhouse (in polish). 